Reseña

\section{Cebreiro Ares, Francisco. El Banco de San Carlos en Galicia (1783-1808). Periferia financiera, plata hispánica y final de Antiguo Régimen monetario. París, Éditions Hispaniques, 2020, 264 pp. ISBN: 978-2853551076.}

El Banco Nacional de San Carlos, fundado por Real Cédula de 2 de junio de 1782, inicia sus operaciones un año después. Sería el primer establecimiento bancario de España con forma de sociedad anónima, con su capital dividido en acciones. Tal y como preveía su norma fundacional, el Banco contará con una extensa red de corresponsales en las principales plazas de comercio -inicialmente treinta comisionados en España y veintiocho fuera-. Los primeros contactos con los corresponsales se presentaban para ocuparse de la suscripción de las acciones y, posteriormente, para atender al negocio bancario y de provisiones al ejército que, entre otros objetos, tenía asignado legislativamente.

Partiendo de su tesis doctoral, defendida en 2018 con el título Circulación monetaria y crédito en Galicia al final del Antiguo Régimen, el autor ahora amplía su capítulo VIII. Dos características marcan el contenido del libro. Por un lado, concentra su estudio en el corresponsal de A Coruña, sin prácticamente referencias a la actividad de otros corresponsales o a la situación general del Banco y, por otro, documentalmente se sustenta en la correspondencia remitida por el corresponsal coruñés al Banco en Madrid. La dificultad manifestada por el autor, y común a esta documentación, es que no se conservan en el Archivo del Banco de España las cartas que la Central remitía a los corresponsales, sino únicamente las respuestas de estos.

La obra se compone de prólogo, introducción, siete capítulos y conclusión, a lo largo de 262 páginas, incluida la bibliografía. La introducción aporta información de interés respecto al panorama económico y social de Galicia en el siglo xviII, y en ella se contextualiza algunos tópicos tales como la incomunicación por carreteras, la falta de industria, la situación del campesinado o el escaso desarrollo de mecanismos bancarios y financieros. Se aborda la nueva etapa de impulso económico nacida de la creación del Arsenal Real del Ferrol (1750) -por sus inversiones - y de los Correos Marítimos en A Coruña (1764) transporte de mercancías y dinero con las colonias-, y sus consecuencias en el aumento del vecindario, en parte proveniente de burguesías periféricas, extranjeros o comerciantes indianos. Para facilitar la comprensión de las operaciones, el autor expone la distinción entre moneda efectiva o real -en piezas - y la de cuenta o ideal -de vellón-, así como sus equivalencias, e incluye un apartado de la letra de cambio. Finalmente, se proporcionan datos relativos a la investigación realizada en el Archivo y el método de trabajo seguido para tratar las 13.523 letras de cambio que se contenían en las 2.503 cartas examinadas (en media una carta cada tres días).

Los siete capítulos están redactados a modo de un diario de operaciones de la oficina coruñesa, ilustrados con profusión de gráficos y cuadros y donde, sobre todo al final de los capítulos, se agrega la información del periodo, proporcionando una visión macro de la actividad y negocio de la oficina y su relación con los flujos monetarios e intermediación. Si bien todas las figuras tienen su numeración, en el texto no se hace referencia a ella, lo que en ocasiones entorpece su seguimiento. Dado el grado de detalle empleado y la exposición estrictamente secuencial de las cartas, sin apoyarse en una mayor agrupación por temas, algunas partes de los capítulos pudieran resultar, en su lectura, relativamente reiterativos.

Son sus títulos: «1. Los orígenes de la factoría: Zelaeta y la búsqueda de accionistas (1783-1785)»; «2. Letras y plata: La formación de una oficina bancaria con Mendinueta (17861790)»; «3. Cambio de política bajo el marqués de Iranda (17911792)»; «4. El giro de la guerra con la Convención (1793-1795)»; «5. Finanzas de la oficina durante la guerra con Inglaterra (1796-1801); «6. Breve optimismo de Amiens (1802-1803)», y «7. Los descuentos de Adalid y la lenta agonía (1802-1808)». Advertir que en la nota 146 (p. 105-)se ha deslizado un error, al indicar que Antonio Galavert era cuñado de Cabarrús, cuando realmente era suegro.

El autor, para la distribución por capítulos, parece fijar un acontecimiento singular y al corresponsal, aunque podría haberlo planteado de cualquier otro modo, pues, en definitiva, son tres las fases de la oficina: la inicial, de puesta en marcha y asentamiento de operaciones (1783-1786); la intermedia, más extensa y fructífera, si bien influida por el devenir de distintas guerras (1787-1802), y la final, cuando comienza un lento declive (1803-1808).

Estas tres fases se corresponderían con la actuación de los corresponsales que estaban al frente. En la inicial serán José Ramos y Francisco Antonio Zelaeta, aunque en enero de 1785 solo quedará el segundo. En la intermedia se nombrará en noviembre de 1785 a Pedro María Mendinueta, lo que generará una contundente reclamación de Zelaeta, el cual, por muchas razones que esgrimió -incluido el trato de favor, pues aquel era primo del marqués de las Hormazas-, quedaría definitivamente apartado. Sin embargo, a lo largo de dieciocho años Mendinueta mostrará su habilidad, buen hacer y tino en su gestión. La final vendrá marcada por la muerte repentina de Mendinueta (19 de marzo de 1803), al que sustituirá Marcial Adalid, primero interinamente y definitivamente desde el 9 de abril de 1803, al tiempo que el Banco aprovecha esa circunstancia para desmantelar parte de la operatoria.

En los tres primeros años, la actividad fundamental de la oficina será la colocación de acciones. A partir de ahí se cen- 
trará en el cobro y pago de efectos y en ofertar letras a pagar por el Banco en Madrid, mas, en su práctica habitual, destacarían: la extracción de pesos fuertes - hacia Bayona conducidos por arrieros o por vía marítima a Londres y Amsterdam-, por los que el Banco percibía determinados ingresos, y el envío de oro a Madrid. Complementariamente, resultaba fundamental la información no financiera que proporcionaban los corresponsales a la Central y, en el caso de Mendinueta, destacaban sus opiniones, tales como el efecto de las comisiones o de los cambios aplicados por el Banco sobre la actividad comercial y bancaria o la ampliación del tipo de operaciones.

Según las conclusiones, la oficina coruñesa exportaba pesos fuertes para el mercado internacional en plata y facilitaba traslados dentro de España, principalmente a Madrid a través de letras de cambio. Durante veinte años exportó -en millones de reales de vellón-: 589,3 en moneda metálica; 179,2 en letras sobre Madrid, y 17,9 sobre delegaciones europeas del Banco. La exportación anual del Banco entre 1786 y 1794 fue de 85,5 millones de pesos fuertes, de los cuales el $16,8 \%$ fue realizado por A Coruña.
Indica el autor que la historiografía precedente del desempeño periférico se circunscribe únicamente al caso gaditano. Hay que matizar que existen trabajos sobre los comisionados - como los de Carnero Lorenzo (2000), Angulo Morales (2002) o Moreno Fernández (2015) - que no han sido considerados en su bibliografía. Con ellos, quizás se hubiera aportado una visión complementaria y ampliada, puesto que las decisiones y comunicaciones de la Central en muchos casos solían ser generales y la particularidad venía de las características propias de la actividad y negocio de cada localidad.

Con todo, extraordinariamente bien recibida sea esta nueva y detallada aportación al conocimiento de la actividad del Banco a través de la vía de sus corresponsales y que tanta repercusión tuvo en el quehacer bancario y financiero.

Rafael Moreno Fernández Banco de España 